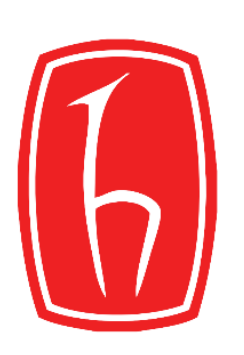

\author{
Hacettepe Üniversitesi Edebiyat Fakültesi Dergisi \\ Hacettepe University Journal of Faculty of Letters \\ Cilt/Volume: 35 Sayı/Number:2
}

Aralık/December 2018

doi: 10.32600/huefd.442392

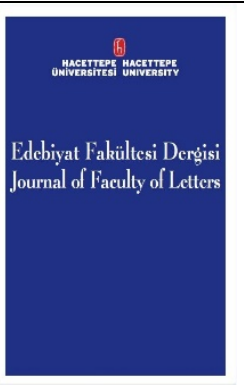

\title{
Bir Osmanlı Müverrihi: Athanasios Komnenos Hypsilantis
}

\author{
An Ottoman Historiographer: Athanasios Komnenos Hypsilantis
}

\author{
Elif Bayraktar TELLAN*
}

Öz

Osmanlı döneminde Rumca yazılmış tarih çalışmaları Osmanlı tarihçiliğinde fazla bilinmemekte ve kullanılmamakta, Osmanlı tarihyazımındaki yerleri yeteri kadar değerlendirilmemektedir. Bu çalışmalardan biri de Athanasios Komnenos Hypsilantis' in yaklaşık kırk yılda tamamladığı ve 1453-1789 yıllarını anlatan kısmı 1870 yılında yayınlanmış olan Ta Meta tin Alosin'dir. Bugüne kadar daha ziyade Yunanca literatürde kullanılan bu çalışma taşıdığı öneme rağmen Osmanlı tarihçiliğinde yeteri kadar değerlendirilmemiştir. Çalışmanın yazarı Athanasios Komnenos Hypsilantis (1711-1789?), Fenerli bir aileden gelmesiyle bağlantılı olarak iyi bir eğitim görmüş, bu sayede önemli mevkilerde hizmet etmiştir. Bulunduğu mevkiler ve bağlantıda olduğu şahıslar sayesinde özellikle kilise meselelerinde, Eflak ve Boğdan voyvodalıklarıyla ilgili olaylarda ve daha sonra Ruslarla olan ilişkilerde yakından gözlem yapabilecek bir konumda yer almıştır. Bu sebeple Hypsilantis’ in çalışması özellikle bu meselelerde farklı bir açıdan sunulan zengin bir içeriğe sahiptir. Bu makalede öncelikle Fenerli bir ailenin Osmanlı dünyasında önemli bir konuma ne şekilde geldiğine güzel bir örnek oluşturan Hypsilantis ailesinin tarihi aydınlatılmaya çalışılacaktır. Daha sonra Hypsilantis'in hayat hikayesiyle paralel olarak çalışmasının içeriği ve üslûbu hakkında daha detaylı bilgi verilecek, Hypsilantis'in Ortodoks kilisesi ve Patrikhanelerin problemlerine dair gözlemleri ve kendini bu meselelerde nasıl konumlandırdığını tespit etmek amacıyla bu konuda yazdıklarına göz atılacaktır. Son olarak Hypsilantis’in çalışması gibi Rumca eserlerin Osmanlı tarihçiliğinde önemli bir yeri olmasına rağmen neden gözardı edilmiş olabileceğinin muhtemel sebepleri değerlendirilecektir.

Anahtar sözcükler: Hypsilantis, Fener aileleri, Osmanlı tarihyazımı, Osmanlı Ortodoks

\begin{abstract}
Historical works rendered in Greek during the Ottoman period are not widely known and used in Ottoman studies and are not typically regarded as part of Ottoman historiography. One such work was written by Athanasios Komnenos Hypsilantis in almost forty years and was only partially published-namely the section narrating the period between 1453 and 1789 - in the year 1870 under the title Ta Meta tin Alosin. This book has been so far used mostly in studies written in Greek, and despite its importance, has not been used widely in Ottoman studies. Due to his Phanariot origins, Hypsilantis received a good education and served in prominent posts. Due to his social status and networks, he was in a position to make first-hand observations on matters related to the Orthodox Church, the principalities of Wallachia and Moldavia, and finally the Russian-Ottoman relations. For this reason, Hypsilantis' work offers valuable material for historians on these issues from a different perspective. In this article I will first attempt to shed light on the history of the Hypsilantis family as a case study of how a Phanariot family comes to prominence in the Ottoman World. Then, I will look at the content and style of Hypsilantis' work as well as his life and examine his observations on the affairs of the Orthodox Patriarchates and how he positions himself in these matters. Finally, I will ponder on the reasons behind the disregard for works in Greek such as Hypsilantis’ in Ottoman historiography despite their importance in Ottoman studies.
\end{abstract}

Keywords: Hypsilantis, Phanariots, Ottoman historiography, Ottoman Orthodox

* Dr. Öğr. Üyesi, İstanbul Medeniyet Üniversitesi, e-posta: elif.bayraktar@medeniyet.edu.tr 


\section{Giriş}

Athanasios Komnenos Hypsilantis ${ }^{1}$ on sekizinci yüzyılda çeşitli kademe devlet görevlerinde hizmet etmiş ve geriye önemli bir tarih kitabı bırakmış bir İstanbulludur. Hypsilantis'in Rumca kaleme alınmış ve yalnızca bir kısmı yayınlanmış olan Ta meta tin Alosin [Düşüşten Sonrası]: 1453-1789² başlıklı çalışmasının bugüne kadar çok az ilgi görmüş olması, Osmanlı tarihyazımı açısından başlı başına ilgi çekici ve üzerinde düşünülmesi gereken bir durumdur. Osmanlı tarihçileri tarafından Ragıb Paşa'nın hekimi olarak bilinen Hypsilantis'in çalışması daha çok Yunanca literatürde kullanılmış, Osmanlı tarihyazımına dair çalışmalarda kendisinin kitabından bugüne kadar nadiren ve yalnızca gayrimüslim tarihyazımı bağlamında bahsedilmiştir. ${ }^{3}$ Dolayısıyla bu yazının amacı, Hypsilantis'in bugüne kadar göz ardı edilmiş olan kitabına dair bilgi vermek ve Osmanlı tarihyazımı içindeki yerini değerlendirmektir.

\section{Hypsilantis ailesi ve Athanasios Komnenos Hypsilantis}

Athanasios Komnenos Hypsilantis, üyeleri on sekizinci yüzyıldan itibaren divan baş tercümanı, donanma tercümanı, Eflak ve Boğdan voyvodası gibi pozisyonlarda görevlendirilmiş olan nüfuzlu Fener ailelerinden birine mensuptur. On altınc1 yüzyıl sonundan itibaren İstanbul'un Fener semtinde bulunan İstanbul Ortodoks Patrikhanesi, yalnızca dini bir kurum olmanın ötesinde aynı zamanda Osmanlı Ortodoks cemaatinin ileri gelen bireylerinin de bulunduğu geniş bir ilişki ağını temsil ediyordu. Sadece din adamları değil, özellikle toplumda maddi güç sahibi olan tüccarlar ve diğer önemli meslek sahipleri de Patrikhane'ye yakın olmak ve bu sosyal çevrenin bir parçası olmak için Fener'de yerleşmeyi tercih ediyorlardı. Patrikhaneyi özellikle maddi olarak yönetebilmek için gerekli nakit parayı sağlayan figürlerin gittikçe önem kazandığı bir dönemde önde gelen Ortodoks aileler ile Patrikhanenin kendi alanlarındaki nüfuzlarından faydalanabildikleri karşıllklı bir ilişkiden bahsedebiliriz. Bu düzen hiçbir şekilde Osmanlı idaresini, Müslümanları veyahut taşradaki unsurları dışarıda tutmuyordu. Fener'de ikamet ediyor olmak bu sosyal çevreye dâhil olmayı kolaylaştıran etmenlerden sadece biriydi. Fener'de yaşayan bu sosyal grubun üyeleri (Fanariotlar) maddi durumları ve içinde bulundukları sosyal çevre sayesinde çocuklarını Avrupa kentlerine eğitim için gönderme imkânına sahiptiler. Böylelikle Fener'de eğitimli bir Osmanlı Ortodoks nesil yetişmeye ve zamanla Osmanlı idari mekanizmasında daha etkin bir şekilde yer almaya başladı. On yedinci yüzyılın ortasından itibaren Fener ailelerinin bazı üyeleri, aldıkları eğitim ve dil bilgileri sayesinde divan tercümanı ve donanma tercümanı olarak görevlendirildiler. On sekizinci yüzyıl başından itibaren de Eflak ve Boğdan voyvodası olarak atanmaya başladılar. Bu pozisyonlar zamanla yalnızca Fenerli ailelere ait bir konum haline geldi (Balc1, 2006, s. 64-67; Philliou, 2009).

Hypsilantis ailesinin tarihi, Osmanlı toplumunda Fanariotların nasıl imkanlarla ve hangi kanallardan önemli mevkilere ulaştığını gösteren güzel bir örnek olduğu için öncelikle aile tarihine bir göz atacağız. Hypsilantis ailesinin bilinen ilk üyelerinin tarihini Bizans dönemine ve Trabzon'a dayandıran kaynaklar mevcuttur (Stamatiadis, 1865, s.136 ve Byzantios, 1851, s.537). Buna göre aile, adını Trabzon'un Hypsilon köyünden alır (Stamatiadis, 1865, s.136). Stamatiadis, "şüpheli bir rivayete göre” Hypsilantis ailesinin henüz 11. yüzyılda Bizans sarayında saygın bir konuma sahip olduğunu, 13. yüzyılda Aleksios Komnenos'un ardından Trabzon'a gittiğini aktarır (Stamatiadis, 1865, s.136). Aile fertleri Trabzon sarayında önemli pozisyonlara sahiptir. En önemlilerinden Konstantin Ksifilinos Hypsilantis, 1390’da İmparator III. Manuel'in kızı Evdokia ile evlenir (Stamatiadis, 1865, s.136 ve Byzantios, 1851, s.537). Bu evliliğe dair erken bir kaynak da 1775'te Leipzig'de basılan Sümela Manastırı tarihine dair bir kitaptır. Kitabın henüz ilk sayfalarında Sümela Manastırı'nda bulunan bir el yazması kodekse dayanarak Konstantin Ksifilinos Hypsilantis'in İmparator Komnenos'un kızıyla yaptığı evlilikten bahsedilir (Kafsokalybitis ve Metaksopoulos, 1775). Diğer yandan bazı yirminci yüzyıl tarihçileri, Hypsilantis ailesinin Trabzon'da

\footnotetext{
${ }^{1}$ Yunan harflerinin transkripsiyonundaki farklı tercihler sebebiyle Hypsilantis, Ypsilantis veya Ipsilantis şeklinde yazılabilir. Bu yazıda daha yaygın olan Hypsilantis tercih edilmiștir.

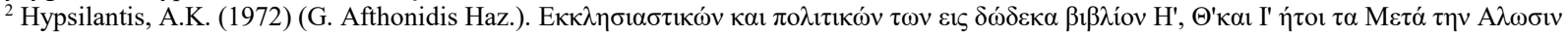
(1453-1789). Atina: Noti Karavia (1870 baskısının yeniden basımı).

${ }^{3}$ Bkz Strauss, J. (1999). The Rise of Non-Muslim Historiography in the Eighteenth Century. K. Fleet (Ed.), Oriente Moderno 18 (79), $217-232$.
} 
Komnenos hanedanıyla evlilik yoluyla kurduğu bu bağlantı hikâyesinin gerçeği yansıtmadığı ve bunun on sekizinci yüzyılda kurgulanmış bir anlatı olduğu görüşündedir (Kazhdan, 1991, s.2211). Patrinelis, kitabın yazılmasına katkıda bulunanlardan Metaksopoulos'un 1775 civarında -tam da Aleksandros Hypsilantis'in Eflak voyvodalığı döneminde- bu bölgede bulunduğunun altını çizer (Patrinelis, 2001, s.185). Sturdza da benzer bir yaklaşımla ailenin tarihini Komnenos hanedanına bağlayan Sümela tarihi yazarının bu çalışmasının karşılığını voyvodadan gördüğünü bildirir (Sturdza, 1983, s.468). Fanariotların kökenlerini Bizans'a dayandırarak kendilerine soylu bir geçmiş yaratma çabası sadece Hypsilantis'lere özgü değildir. Diğer Fener aileleri de geçmişlerine dair benzer çabalarda bulunmuş, fakat bu iddiaların geçerliliği sorgulanmıştır (Mango, 1973, s.41-66). Pallis'e göreyse Arygropoulos, Kantakuzenos, Rangavis, Mourouzis ve Hypsilantis'lerin Bizans hanedanlarına dayanması diğerlerinden daha mümkünken Mavrokordatos, Karacas ve Soutzos aileleri ancak Osmanlı döneminde güç kazanmaya başlamıştır (Pallis, 1951, s.2). Ailelerin aralarındaki husumet ve rekabet, asalet iddialarının rakipleri tarafından da sorgulanmasına sebep olmuştur. Örneğin, Nikolas Soutzou'nun Hypsilanti ailesinin kürkçülükten geldiğini, Mourouzi ailesinin de Saray'ın tedarikçisi olduğunu iddia etmesi üzerine, Hypsilantis de Soutzos ailesinin zamanında sütçülük yaptığını, isminin buradan geldiğini öne sürmüştür (Iorga, 2000, s.229 ve Hypsilantis, 1972, s.405). ${ }^{4}$

Athanasios Hypsilantis, Trabzon'daki hanedan ailesiyle olan bağını vurgulamak için Komnenos ismini soyadına eklemiştir (Iorga, 2000, s.227). Fakat kitabın farklı bölümlerinden anladığımız kadarıyla Athanasios'un Komnenos bağlantısına dair tavrı zaman içinde değişiklik göstermiş olmalıdır. Komnenos bağlantısını soyadı yoluyla sahiplenen Athanasios, aile tarihinin Bizans kökenlerine ilişkin bilgilere çalışmasının bir kısmında yer verirken (Hypsilantis, 1972, s.8, 11) diğer bir kısmındaysa Trabzon'dan İstanbul'a geldikten sonra uğraştıkları Karadeniz ticaretinin ailenin serveti üzerindeki etkisinin üzerinde daha çok durmuştur (Hypsilantis 1972, Ek, 170). ${ }^{5}$ Komnenos bağlantısına inanmayan Sturdza da Athanasios'un önceki yazılarında bu iddiayı dile getirmediğini bildirir (Sturdza, 1983, s.468).

Hypsilantislerin on yedinci ve on dokuzuncu yüzyıl arasındaki tarihine dair ayrıntılar, özellikle aile fertlerinin akrabalık ilişkileri konusunda kaynaklarda farklılık göstermektedir. Hypsilantis, kendi kitabının on ikinci bölümündeki Aleksandros Hypsilantis'le ilgili kısmında Hypsilantis ailesinin tarihine de ayrıntılı olarak değinir. Buna göre Trabzon'un önde gelen Rumlarından olan Kyriakos'un Triantafyllos ve Konstantin isimli oğulları vardır. Triantafyllos 1613 doğumludur ve Sümela Manastırı'nda görevlidir. Konstantin ölünce oğlu Ioannis amcası Triantafyllos ile birlikte yaşamaya başlar. Triantafyllos'un on beş yaşında çok güzel bir kızı vardır. Trabzon'un paşası bir gün tebdil-i kıyafet gezerken kızı görür, kendisine âşı olur ve onunla evlenmek ister. Triantafyllos kızının Hristiyan olarak kalmasını istediği için paşayı bir süre oyaladıktan sonra ailesi ve yeğeni ile birlikte İstanbul'a kaçar. Trabzon'da sahip olduklarını ve ailelerinin bir kısmını geride bırakırlar ve İstanbul Boğazı'nda Yeniköy'e yerleşip yeni bir hayat kurarlar. Büyük tekneleriyle kaptanlara sermaye sağlayarak Karadeniz'de ticaretle uğraşırlar. Triantafyllos ve yeğeni Ioannis ticaret sayesinde daha da zengin olurlar, fakat Ioannis amcasından daha başarılı olur. (Hypsilantis, 1972, Ek, s.169-170). On dokuzuncu yüzyıla ait diğer bir grup kaynağa göreyse on yedinci yüzyılda Trabzon'dan İstanbul'a geldiği kabul edilen ailenin adı geçen en eski üyesi 1665 'te İstanbul'a gelen Antioch'tur, fakat kendisine dair daha fazla bilgi verilmemektedir (Stamatiadis, 1865, s.136 ve Boutyras, 1890, s.35).

Hypsilantisler on sekizinci yüzyıldan itibaren bazı önemli mevkilerde görev almaya başlarlar. Hypsilantis'e göre Trabzon'dan İstanbul'a ilk gelenlerden Ioannis, Kudüs'teki Kutsal Kabir'e (Agios Tafos/Holy Sepulchre) giderek hacı olur. ${ }^{6}$ Hacı Ioannis'in Konstantin, Manolakis, Antonios isimli oğulları

\footnotetext{
${ }^{4}$ Soutzos ailesi için bkz. Sturdza, 1983, s.417-425.

${ }^{5}$ Komnenos-Hypsilantis bağından 1765-1768 yılları arasında tamamladığı sekizinci bölümde bahseder (Hypsilantis, 1972, s.8, 11). Bizans döneminden bahsetmeyip on yedinci yüzyıldan itibaren anlatmaya başladığı aile tarihi ise, 1870 baskısında bulunmayan, 1909 'da Kerameus tarafından yayınlanıp 1972 baskısına dâhil edilen on ikinci bölümden seçmeler kısmında yer alır.

${ }^{6}$ Tüccarların Hacı unvanıyla ilgili bkz. Davidova, 2013, s. 132-139.
} 
ile Eleni ve Tarsia isimli kızları dünyaya gelir. ${ }^{7}$ Manolakis (Manuel) Hypsilantis, kız kardeşi Tarsia’nın eşinden sonra sarayda kürkçübaşı olur ve yaklaşık olarak 1700-1730 yılları arasında İstanbul'da etkin bir rol oynar ${ }^{8}$ (Hypsilantis, 1972, Ek, s.170 ve Byzantios, 1851, s.537). Hypsilantis, Manuel'in 1714'te Sadrazam Damat Ali Paşa'nın kürkçübaşı olduğu sırada İskenderiye patriği Kosmas'ın İstanbul patriği olmasını sağladığını yazar (Hypsilantis, 1972, s.295). Ailenin diğer üyelerinden Konstantin ise Boğdan voyvodası Rakovitza'nın postelniki olur. Byzantios'a göre Konstantin Patrikhane'de megas rhetor ${ }^{9}$ olarak görevlidir ve Ioannis adlı bir oğlu vardır (Byzantios, 1851, s.537). Konstantin'in oğlu Ioannis Ağa ${ }^{10}$ Smaragda Mamonas ile evlenir ve bu evlilikten oğulları Aleksandros doğar (Stamatiadis, 1865, s.137; Byzantios, 1851, s.537).

Aleksandros'tan itibaren aileye dair bilgilerimiz on dokuzuncu yüzyıl kaynaklarında daha nettir, zira Aleksandros 1774'te divan tercümanı olacaktır (Stamatiadis, 1865, s.137; Boutyras, 1890, s.34; Byzantios, 1851, s.537). Bir diğer on sekizinci yüzy1l tarihçisi olan Kaisarios Dapontes, Aleksandros'un kap1 kethüdalığından Eflak voyvodalığına yükseldiğini anlatır. Aleksandros, buradaki görevinden sonra bir ara sürgüne gönderilmiş, sonra İstanbul'a dönmüştür. Dapontes, Aleksandros'un Eflak'ta edindiği maddi imkanlar sayesinde Kuruçeşme'de çok pahalı bir evde yaşadığını da ekler (Dapontes, 1872, s.172). Aleksandros'un 1760 yılında Konstantin isimli bir oğlu olur. Bir süre Almanya'da bulunan Konstantin, divan tercüman1, Boğdan (1799-1801) ve Eflak (1802-1806) voyvodas1 (Philliou, 2004, s.352) olarak görev yaptıktan sonra Rusya'da ölür (Stamatiadis, 1865, s.151ve Boutyras, 1890, s.38-39; Byzantios, 1851, s.537). Konstantin'in, Elizabeth ile Eflak'ta yaptığı ikinci evliğinden beş oğlu ve bir kızı olur. Oğullarından ikisi Yunanistan'ın bağımsızlığındaki en önemli aktörlerden, Filiki Etaireia mensupları Aleksandros ve Dimitrios'tur (Byzantios, 1851, s.527; Stamatiadis, 1865, s.151) ${ }^{11}$ Bu dönemde Hypsilantis ailesinin yeni bir devlet kurmak için savaşan üyelerinin ünü okyanus ötesine ulaşmıştır. 1825'te Amerika'nın Michigan eyaletinde yeni kurulmakta olan bir kasabaya isim düşünülürken o sırada Amerika'nın doğu kıyılarında çok popüler olan Demetrius (Dimitri) Hypsilantis'ten esinlenilerek kasabaya Ypsilanti adının verilmesine karar verilir (Foster, 1857, s.9-10).

Athanasios Komnenos Hypsilantis, Osmanlı dünyasında önemli bir yeri olan bu aile soyağacının neresinde yer almaktadır? On dokuzuncu yüzyıl kaynakları Athanasios hakkında ya bilgi vermez ya da birbiriyle çelişen bilgilere yer verirler. ${ }^{12}$ Athanasios kendi çalışmasının bir yerinde Ioannis Ağg'nın akrabası olduğunu bildirir (Hypsilantis, 1972, s.137). Sturdza'nın verdiği soyağacına göre Athanasios, Kyriakos'un diğer bir oğlu olan Hadji Savouli’nin soyundan gelir (Sturdza, 1983, s.472).

\footnotetext{
${ }^{7}$ Stamatiadis'e göre Ioannis, Antioch’un ilk oğludur. İyi eğitimli ve erdemli biri olan Ioannis, "Slav" kiliselerinin birleşmesi fikrini öne sürmüş, fakat sonradan idam edilmiştir. (Stamatiadis, 1865, s.136-137ve Boutyras, 1890, s.35). Boutyras ise Ioannis'in tercüman olduğunu bildirir (Boutryras, 1890, s.35). Slav kiliselerinin birleşmesi derken kastedilen 1767 ve 1768 'de İpek ve Ohri başpiskoposlukları İstanbul Patrikhanesi’ne bağlanmasıdır. Ioannis Hypsilantis'in bunu ilk öneren kişi olduğu Boutyras tarafindan da belirtilmiştir (Boutyras, 1890, s.35).

${ }^{8}$ Manuel (Manolakis) Hypsilantis, Osmanlı tarihlerinde Patrona Halil isyanı sırasında adı geçen "kürkçü Manol" olmalıdır. Bu kaynaklarda anlatılan hikâyeye göre isyan sırasında III. Ahmed'in İbrahim Paşa'yı katlettirmediği, Paşanın cesedini isteyenlere bunun yerine Kürkçü Manol’ün cansız bedenini gösterdiği, İbrahim Paşa'nın ise saklandığı söylentileri yayılmıştı (Aktepe, 1958, s. 152ve Uzunçarşılı, 2007, s. 209). Hakan Yılmaz Patrona Halil isyanıyla ilgili mühimme kayıtlarını yeniden incelemiştir, buna göre "Eflâk ve Boğdan voyvodalarının ve patriklerin azl [ve] nasblarına karış[an]" kürkçübaşı Manol, isyan sırasında Boğdan voyvodasının yanına kaçmış ve yakalanması emredilmiştir (Yılmaz, 2016, s. 416417ve Altınay, 1988, s.109-110). Kürkçü Manol kaynaklarda "Rum taifesinden, sarı bıyıklı, gök gözlü, tıraş zımmi”" olarak nitelendirilmiştir (Altınay, 1988, s.109). Hypsilantis de Manuel'in Patmos'da bir okul kurduğu da söylenir (Iorga, 2000, s.199).

${ }_{9}^{9}$ Patrikhanedeki onursal pozisyonlardan biri. Bizans döneminde dini eğitimden sorumlu olan kişiydi. Patrikhanedeki onursal mevkiler ve tanımları için bkz. Papadopoullos, 1990, s.60-85.

${ }^{10}$ Byzantios'a ve Dapontes'e göre Konstantin'in oğlu, Stamatiadis ve Boutyras'a göreyse Athanasios'un oğlu olan “Ağa Yannaki”. Prusya ile yapılan antlaşmada Osmanlı Devleti tarafinda görev almıştır (Stamatiadis, 1865, s.137).

${ }^{11}$ Filiki Etaireia için bkz. Frangos, G.D. (1971) The Philiki Etaireia, 1814-1821: A social and historical analysis. Doktora Tezi, Columbia Üniversitesi, New York. Baş tercümanlık görevlerinde bulunan Konstantin ve Aleksandros Hypsilantis ile ilgili Stamatiadis'in çalışmasında da detaylı bilgi mevcuttur (Stamatiadis, 1865, s.135-141, 151-155).

${ }^{12}$ Hypsilantis ailesinden bahseden on dokuzuncu yüzyıl kaynaklarından Stamatiadis, Athanasios'tan, Ioannis'in kardeşi olarak bahseder. Stamatiadis'e göre Ioannis Hypsilantis Rumların Bizans İmparatorluğu'nun düşüşünden 1700'lere kadar gelen tarihini yazmıştır (Stamatiadis, 1865, s.136). Athanasios hakkındaysa fazla bir bilgi vermez, yalnızca Antioch'un diğer oğlu olduğunu ve Sultan III. Mustafa'nın sevgisini kazanmış bir isim olduğunu belirtir (Stamatiadis, 1865, s.137). Stamatiadis'in yazdığı sırada Athanasios'un kitabının henüz yayınlanmadığını göz önünde bulundurursak, Stamatiadis'in Ioannis ve Athanasios'u karıştırmış olabileceğini düşünebiliriz. Kardeş olduklarına dair bilgi de muhtemelen yanlıştır çünkü Athanasios, Ioannis'in torunu Ağa Ioannis ile aynı dönemde (1724-1727) Boğdan'da bulunmuştur (Hypsilantis, 1972, s.137).
} 
Athanasios'un kitabında yer yer kendi hayat hikayesinden bölümlere rastlamak mümkündür. Buna göre Athanasios Komnenos Hypsilantis 29 Ağustos 1711'de annesi Kassandra'nın Tarabya'daki evinde doğmuştur. Çalışmasını kaleme aldığı sırada evin Terkos (Derkoi) metropolitine ait olduğunu yazar. Anne tarafindan dedesi Aphentoulis Tzanetou'nun, Kazak hatmanı Mazepa'nın baş tüccarı ve tedarikçisi olduğunu bildirir (Hypsilantis, 1972, s.284). Temmuz 1724'te eğitim görmek için Yaş’a gider ve 1727'ye kadar Boğdan voyvodası Mihail Rakovitza'nın çocuklarıyla birlikte Sakızlı Nathaniel Kallonari'den dersler alır. Yukarıda bahsettiğimiz akrabası Ioanni A ğa'nın (Ăga Yannaki) yanında kalması bu döneme rastlar. Voyvoda Rakovitza'nın görevi son bulunca İstanbul'a dönerler ve Kallonari ile derslere devam eder (Hypsilantis, 1972, s.137, 322-326; Legrand, 1881, s.xii). Fener ailelerinin oğullarında yaygın olduğu üzere Athanasios da 1731'de İstanbul'dan ayrılıp eğitim için Padova, Bologna ve Floransa'ya gider (Hypsilantis, 1972, s.332). ${ }^{13} 16$ Ocak 1738 'de İstanbul'a döndüğünde felsefe ve tıp doktoru unvanlarına sahiptir (Hypsilantis, 1972, s. 343). 1739'da Boğdan voyvodası Grigorios Gkikas tarafından başhekim olarak davet edildiği Yaş'a gider (Hypsilantis, 1972, s.344). Ioannis Anastasios, 1741'de Athanasios'un annesi Kassandra'y1 ve babas1 Theodoros'u veba yüzünden kaybettiğini bildirir (Anastasios, 1981, s.125).

Athanasios'un İstanbul'a döndükten sonra Ragıb Paşa'nın hizmetine girmesi üzerine ikisinin hayat hikayeleri bir süreliğine kesişir. Ragıb Paşa, 1720’lerden itibaren eğitimi ve özellikle Farsça bilgisi sayesinde çeşitli memuriyetlerde görevlendirilmiş, İran, Rusya ve Avusturya ile olan görüşmelerde delege olarak bulunmuş, 1741 'de reisülküttaplık makamına getirilmiştir. İran'la yaşanan sorunlar sırasında mezheplerle ilgili öne sürdüğü bir çözüm yolu yüzünden Darüssaade Ağası Hacı Beşir Ağa ile arası açılınca 23 Nisan 1744'te Mısır valiliği göreviyle vezirliğge yükseltilir, fakat İstanbul'dan da uzaklaştırılmış olur (Aydıner, 2007, s.403-404). Görevlendirildiği yerlerde Ragıb Paşa'ya tabip olarak eşlik eden Athanasios Hypsilantis'in çalışması, İmparatorluğun İstanbul'dan uzak bölgelerine gönderilen devlet görevlilerinin tecrübelerine dair farklı bir bakış açısı sunması açısından önemlidir. Athanasios Mısır valisi (igemonas) ${ }^{14}$ olan Ragıb Paşa ile birlikte öncelikle Mayıs 1744'te İskenderiye'ye gider (Hypsilantis, 1972, s.352). Hypsilantis, Ragıb Paşa Aydın muhassılı (igemonas) olarak görevlendirilince 6 Ocak 1744'te yola çıarak tehlikeli bir yolculuk sonunda 8 Şubat'ta Aydın'a (Güzelhisar) ulaştıklarını anlatır (Hypsilantis, 1972, s.363-364). Ragıb Paşa, tayin edildiği Sayda valiliğine gitmeyince bu sefer Rakka eyaletine tayin edilir. (Aydıner, 2007, s.404). Hypsilantis de Ragıb Paşa'nın Kasım 1750'de görevlendirilmesi üzerine iki ay 14 gün süren çileli bir yolculuktan sonra 8 Şubat 1751'de Edessa'ya (Urfa) ulaştıklarını bildirir (Hypsilantis, 1972, s.365). Ragıb Paşa'nın becayiş ile Halep'e gitmesi üzerine- Hypsilantis’in ifadesiyle Halep valisi (igemonas) olunca- Athanasios da 13 Ağustos 1755'te Halep'e ulaşır (Hypsilantis, 1972, s.372). Eyaletlerde başarılı faaliyetlerde bulunan Ragıb Paşa Şam'a tayin edilmişken, henüz göreve başlamadan bu sefer Sadârete tayin edilir (Aydıner, 2007, s. 404). Athanasios Hypsilantis de 1756 sonunda azledilen Mustafa Paşa'nın yerine Sadrazamlık makamına (vezaret-i uzma) tayin edilen Ragıb Paşa ile beraber Şubat ayında İstanbul'a döndügünü bildirir (Hypsilantis, 1972, s. 373-374). Hypsilantis, hastalanan Ragıb Paşa'nın 28 Mart 1763 Cuma gecesi vefat ettiğini kaydeder (Hypsilantis, 1972, s.395-396).

Athanasios, Ragıb Paşa'nın başhekimi olmasının yanısıra İstanbul'a döndükten sonra Patrikhane ve Eflak-Boğdan voyvodalıklarıyla ilişkili görevlerde bulunur. 26 Temmuz 1759'da İstanbul Patrikhanesi'nde skevofilaks ${ }^{15}$ olarak görevlendirilmiştir (Hypsilantis, 1972, s.383). 1764'te Bükreş'te spatharios ${ }^{16}$ olarak görev alır (Hypsilantis, 1972, s.401). 1769'da Eflak voyvodası Grigorios Gkikas'1n kapı kethüdası olur, sonrasındaysa farklı görevlerde bulunur (Hypsilantis, 1972, s.438). Birçok kaynak 1789'a kadar yaşadığını belirtip kesin bir tarih vermezken Dimitrakopoulos, Nisan 1789'a kadar yaşadığını yazar (Dimitrakopoulos, 1872, s.187; Kyriakos, 1898, s.142). Kitabının editörü Afthonidis de kesin bir tarih vermez (Hypsilantis,

\footnotetext{
${ }^{13}$ Fener ailelerindeki üniversite eğitiminin zannedildiği kadar yaygın olmadığına dair bkz. Patrinelis, 2001, s.189.

${ }^{14}$ Hypsilantis'in kullandığı terimler ve ifadeler parantez içinde italik olarak verilmiştir.

${ }^{15}$ Osmanlı döneminde Patrikhaneyle ilişkili bir diğer onursal pozisyon. Bizans döneminde literal olarak Kilise hazinesindeki kutsal ayin kaplarını ve eşyalarını korumaktan sorumlu, önemli bir mevki idi. (Magdalino, Talbot, 1991, s.1909-1910 ve Papadopoullos, 1990, s.64).

${ }^{16}$ Geçmişi Roma dönemine dayanan, zamanla onursal bir mevki haline gelen, Osmanlı döneminde Eflak ve Boğdan voyvodalıklarıyla ilişkili bir mevki.
} 
1972, s.ix). Kızı Elizabeth'in (Saftitza) yaklaşık olarak 1845'e kadar İstanbul'da yaşadığı ve Yeniköy'de hayatını kaybettiği bilinmektedir (Hypsilantis, 1972, s.ix; Legrand, 1881, s.xii; Boutyras, 1890, s.36).

Editör Afthonidis'in önsözde bildirdiğine göre Athanasios'un İstanbul'da iki evi vardır ve biri Yeniköy'de Aya Yorgi iskelesinin yanında (1870 itibariyle Lambiki ailesinin yaşadığı) bir yazlık ev, diğeri ise Fener sahilinde (sonradan Doktor Saranti'nin elinde olan) bir kışlık evdir. Afthonidis, Fener' deki evin yalnızca kâgir kısmının kalmış olduğunu, fakat birinci kattaki ahşap plakalarda İstanbul Patriği Serafeim'in (1757-1761) ve Kudüs Patriği Parthenios'un (1737-1766) epigramları olduğunu belirtir ve bu epigramların metnine önsözde yer verir (Hypsilantis, 1972, s.ix ve Boutyras, 1890, s.36). ${ }^{17}$ Ayrıca Tarabya'da Hypsilantis ailesine ait olan "Hypsilanti yalısı" aile üyelerinden bazılarının Rusya’ya kaçması üzerine müsadere edilerek 1807 'de Fransız elçiliğine verilmiştir. ${ }^{18}$ Melling'in bir gravürü yalının on dokuzuncu yüzyıl başındaki durumunu tasvir eder. 1913'teki yangında yalının bir kısmı yanmıştır (Tibet, 1994, s. 185-186). ${ }^{19}$

Buraya kadar vermiş olduğumuz Hypsilantis ailesinin tarihi ve Athanasios Komnenos Hypsilantis'in kişisel hayat hikayesi, bir Fener ailesinin hangi koşullarda ortaya çıkıp geliştiğini, on yedinci yüzyılın başından on sekizinci yüzyıl sonuna kadar Osmanlı dünyası içinde nasıl konumlandığını görmemiz açısından önemlidir. Athanasios Komnenos Hypsilantis de böyle bir ailenin bir üyesi olarak, eğitimi ve mesleki yeterlilikleriyle edindiği mevki sayesinde Osmanlı idaresinde üst pozisyonlara yakın kişilerle bağlantılı olmuştur. Bu konumun getirdiği avantajlar, bundan sonraki bölümlerde göreceğimiz gibi Ta Meta tin Alosin'in içeriğine yansımış ve eserin Osmanlı tarihçileri için taşıdığı değeri artıran bir unsur haline gelmiştir.

\section{Hypsilantis'in Çalışmaları ve Ta Meta tin Alosin (1453-1789)}

Hypsilantis toplamda on iki ciltten oluşan çalışmasını 1748-1789 yılları arasında bulunduğu Manisa, Urfa, Halep, Kahire ve son olarak İstanbul'da yazmıştır. Athanasios evinden uzakta bulunduğu zor şartlar altında tarih yazmayı muhtemelen bir sığınak olarak görmüş olmalıdır. Yazma ciltler Sina Başbiskoposu Konstantin tarafindan, s1k sık babasının çalışmasından bahseden Athanasios'un İstanbul'daki kızı Saftitza'dan ödünç alınıp manastır kütüphanesine götürülmüş, bir daha da geri verilmemiştir (Hypsilantis, 1972, ix ve Anastasios, 1981, s.130). On ciltte toplanan on iki bölümlük çalışmanın el yazması Sina Manastırı'nda korunmaktayken, 1453-1789 dönemini kapsayan sekiz, dokuz ve onuncu bölümler, 1870 yılında arhimandrit Germanos Afthonidis ${ }^{20}$ tarafından İstanbul'da I.A. Vretos matbaasında yayınlanmıştır. 1909 yılında A. Papadopoulos-Kerameus çalışmanın bazı eksiklerini ve yayınlanmamış olan on ikinci kitaptan seçtiği bazı bölümleri 1909 yılında başka bir edisyon içinde yayınlamıştır. ${ }^{21} 1972$ yılında Atina'da yapılan bir tıpkıbasıma hem 1870 baskısı, hem de 1909 yılında tamamlanan eksikler dahil edilmiştir. ${ }^{22}$ Günümüzde el yazmasının dijital görüntülerine ABD Kongre Kütüphanesi’nden ulaşmak mümkündür. ${ }^{23}$

\footnotetext{
${ }^{17}$ Bir gezi kitabında da Cibali'deki Aya Nikola Kilisesi kompleksinde bulunan bir binanın, "hekim Manuel Hypsilanti”ye ait olduğu kaydedilmiştir (Massavetas, 2013, s.121).

${ }^{18}$ İpsilantis ailesinin Rusya’ya gidişi ve burada yaşadıklarıyla ilgili Rus arşivlerine dayanan bir çalışma için bkz. Arš, G. L. (1985). On the Life in Russia of the Greek Patriotic Family of Ypsilanti. Balkan Studies, 26, 73-90.

${ }^{19}$ Fransız Büyükelçiliği’nin yazlık yalısı olarak 1989-2012 yılları arasında Marmara Üniversitesi Fransızca Siyaset Bilimi ve Kamu Yönetimi bölümüne tahsis edilmiştir. http://scpo.siyasal.marmara.edu.tr/genel-bilgiler/bolum-hakkinda/ Erişim Tarihi 6 Haziran 2018.

${ }^{20}$ Germanos Afthonidis (1823-1895) İstanbul doğumlu bir din adamı, müzikolog ve âlimdir. İstanbul'da Patrikhane Akademisi'nde eğitim

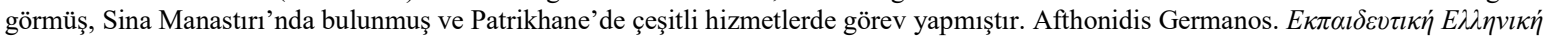

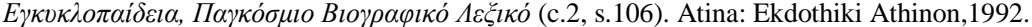

${ }^{21} 1972$ tıpkıbasımının ekler bölümünde, Hurmuzaki edisyonunun XIII. cildinden A. Papadopoulos- Kerameus’un hazırladığı bölüm (161-192. sayfalar) bulunmaktadır. Hurmuzaki E. (1909), Documente privitoare la istoria Românilor, c.13, Bükreş. Ayrıca P.A. Dethier tarafindan hazırlanan fakat basımı tamamlanamayan bir derleme içinde, Hypsilantis'in çalışmasının II. Mehmed dönemine ait olan bölümüne metin üzerinde yapılan küçük düzeltmelerle yer verilmiştir. İstanbul'un fethine dair metinlerin yer aldığı bu nadir eserin bir kopyası Atina'da Gennadious Kütüphanesi’nde bulunmaktadır.

${ }^{22} \mathrm{Bu}$ çalışma için 1972 Atina baskısı kullanılmıştır.

${ }^{23}$ Manuscripts in St. Catherine’s Monastery, Mount Sinai, Greek Manuscripts 1395, Athanasios Komnenos Hypselantos. https://www.loc.gov/collections/manuscripts-in-st-catherines-monastery-mount-sinai/?fa=contributor:athanasios+komnenos+hypselantos Erişim tarihi 5 Haziran 2018.
} 
Athanasios Komnenos Hypsilantis, çalışmasını babası Theodoros ve annesi Kasandra Tzanetou'ya adamıştır. Çalışmanın Athanasios'a ait olan önsözünde on iki bölümün her birinin hangi dönemi kapsadığı ve nerede tamamlandığına dair bilgiler mevcuttur (Hypsilantis, 1972, s.xviii- xxxi ve Anastasios, 1981, s.130-133). Buna göre birinci bölüm Ioulious Kaisaros döneminden başlayıp Byzantion piskoposu Aziz Laurentios'un ölümüne kadar gelir ve 268 y1llık bir dönemi kapsar. Bu bölüm Manisa'da (Aydın Güzelhisart) bulunduğu sırada (1748-1750) tamamlanmıştır (Hypsilantis, 1972, s.xviii). Çalışmanın ikinci bölümü Byzantion piskoposu Aziz Alypios döneminden Patrik I. Paulos (Günah çıkaran, Confessor) zamanına kadar olan 172 senelik bir dönemi kapsar. Bu bölüm Athanasios'un Edessa'da (Urfa) bulunduğu dönemde, Kasım 1752'de tamamlanmış ve Kudüs patriği Parthenios'a ithaf edilmiştir. Bu bölümle ilgili bilgi verirken, aşiretlerin ve çeşitli mezheplerden Hristiyanların bulunduğu bu bölgedeki yaşama tecrübelerinden ve bu bölümü yazarken kaynaklara ulaşmada çektiği sıkıntılardan bahseder (Hypsilantis, 1972, s.xviii-xxi). Üçüncü bölüm I. Paulos ile Patrik Euthymios dönemini içeren 155 yılı (340-496) kapsar. Öğretmeni Efes metropoliti Nathaniel Kallonares'e ithaf edilmiş ve 1752'de Osroinis-Edessa'da (Urfa) tamamlanmıştır (Hypsilantis, 1972, s. xxi-xxiii) Dördüncü bölüm İstanbul patriği Makedonias dönemiyle Patrik Thoma'nın ölümü arasındaki 113 senelik dönemi (494-610) içerir ve Aralık 1753’te OsroinisEdessa'da (Urfa) tamamlanmıştır (Hypsilantis, 1972, s.xxiii). Beşinci bölüm (610-930) Patrik Sergios döneminden başlar ve Patrik Nikolaos Mystikos döneminin sonuna kadar gelir. İskenderiye Patriği Matheos'a ithaf edilmiştir. Temmuz 1755'te yine Edessa'da (Urfa) tamamlanmıştır (Hypsilantis, 1972, s. xiii-xiv.) Altıncı bölüm Patrik II. Stefanos zamanında başlar, Patrik Ioannis Kamateros dönemi sonunda biter (931-1207). Aralık 1756'da Halep'te tamamlanan bu bölüm, Athanasios'un o sırada Maksimos'a karş1 savunduğu metropolit Sofronios'a ithaf edilmiştir (Hypsilantis, 1972, s. xxv-xxviii.) Yedinci bölüm (12081453) Mikhael Autorianos zamanından İstanbul'un fethine kadar olan bölümü kapsar ve İstanbul, Fener'de 1761 'de tamamlanmıştır (Hypsilantis, 1972, s. xxiii). ${ }^{24}$

Editör Afthonidis'in yayınlamayı seçtiği kısım sekizinci bölümle başlar. Yayınlanmış olan bölümlerin nerede ve ne zaman tamamlandığını önsözden değil, her bir bölümün sonundan öğreniriz. Buna göre sekizinci bölüm İstanbul'un fethinden Patrik II. Kallinikos'un ölümüne kadar olan dönemi kapsar (1453-1702) (Hypsilantis, 1972, s.3-239). Bu bölüm Yeniköy’deki ailesinin evinde üç senede (1765-Eylül 1768) tamamlanmıştır. Hypsilantis, bu bölümü yazarken farklı dillerde birçok kaynak kullandığını kaydetmiş, fakat bunların hangileri olduğunu belirtmemiştir (Hypsilantis, 1972, s.239). Johann Strauss, Hypsilantis'in 1710'a kadar gelen olayları anlatırken Dimitri Kantemir'in çalışmasını hatalarıyla birlikte birebir takip ettiğini, bazı yerlerde ise güncellemeler yaptığını tespit etmiştir. Osmanlı tarihçilerinden de en azından 1740'ta İbrahim Müteferrika tarafından basılmış olan Raşid Tarihi'ni kullandığını belirtir, fakat hicri tarihlerin nadiren gösterildiği geri kalan kısım için temel olarak Osmanlı kaynakları haricindeki çalışmalardan yararlanmış olabileceğini tahmin eder (Strauss, 1999, s.227-228).

Dokuzuncu bölüm Patrik II. Gabriel ile Patrik Samuel dönemleri arasını (1702-1768) anlatır, 1782'de Yeniköy'deki evde tamamlanmıştır (Hypsilantis, 1972, s. 419). Onuncu bölüm Patrik Meletios-Patrik Prokopios dönemini, yani 1768-1789 arasındaki 21 seneyi anlatır. 1771'de Fener'de yazılmaya başlanıp 1789'da Yeniköy'de tamamlanmıştır (Hypsilantis, 1972, s.713). Bu bölümlerin önemli bir kısmı yazarın yaşadığı veya yakınlarının tanıklık ettiği olayları anlatır.

Önsözdeki bilgilere dönecek olursak, on birinci bölümün ilk kısmı İskenderiye'de yazılmış bir İran tarihidir. Athanasios bu bölümler için Sina'daki Azize Katerina Manastırı'nın ve İskenderiye Patrikhanesi'nin kütüphanelerinden faydalanmıştır. Yazarın Fener'deki yeni evinde 1775'te tamamlanan ikinci kısım Arapların tarihini konu alır. Son bölüm olan on ikinci kitap ise Fransa ve Almanya tarihleriyle ilgilidir (Hypsilantis, 1972, s.xxxi). Kitabın sonunda Osmanlı Devleti'nin kurumları, görevlileri, idaresi, donanma, Osmanlı idaresinde Araplar, Tatarlar ve Arnavutlar, Eflak, Boğdan ve Kıbrıs hakkında bilgi veren bir ekler bölümü bulunur (Hypsilantis, 1972, s.717-804).

\footnotetext{
${ }^{24} \mathrm{El}$ yazması olarak bulunan bu ilk yedi bölüm henüz yayınlanmamıştır ve bu makalenin yazarı tarafından incelenmemiştir. İçeriğe dair bilgiler Ta Meta tin Alosin'den alınmıştır.
} 
Afthonidis'in kullandığg yazmanın bölümlerinden eksik olan bir kısmı yukarıda da değindiğimiz gibi Halki (Heybeliada) Kütüphanesi'nde A. Papadopoulos-Kerameus tarafindan bulunup başka bir koleksiyonda yayınlanmış, daha sonra 1972 Atina'da yapılan tıpkıbasıma dahil edilmiştir. Tıpkıbasıma dahil edilen bölümlerden biri de on ikinci kitabın bir kısmı olan, Osmanlı döneminde yaşamış önemli Ortodoksların hayat hikayelerinden bahseden bölümdür (Anastasios, 1981, s.132). Bu bölümde Hypsilantis'in kendi ailesi dahil, Osmanlı döneminde yaşamış ve birçok önemli Ortodoks isim hakkında henüz yayınlanmamış bilgiler mevcuttur. Bu isimler arasında tercümanlar, patrikler, voyvodalar ve âlimler bulunmaktadır (Hypsilantis, 1971, Ek, s.161-192).

Yayınlanmış bölümlerin içeriği, özellikle son iki bölümü oluşturan dokuzuncu ve onuncu bölümlerde yazarın yaşadığı dönemi birincil kaynak olarak anlatması, on sekizinci yüzyıl Osmanlı tarihi açısından çalışmayı son derece değerli bir kaynak haline getirmektedir. Bazı araştırmacılar Hypsilantis'in üslubunun sıkıcı ve renksiz olduğu görüşünde olsa da (Iorga, 2000, s.228) farklı bir perspektiften sunulan ayrıntılar, hikayeler ve anekdotlar on sekizinci yüzyıl tarihçileri için bir hazine değerindedir. Çalışma temelde patriklerin görev yaptığı yıllara göre bölümlendirilmiştir, fakat aynı zamanda hangi sultanın ne zaman tahta çıktığı ara bölümlerde başlık olarak belirtilmiştir. Başlıklarda verilen miladi tarihlerin karş1lık geldiği hicri seneler çoğu zaman belirtilmiştir. 1768'den itibaren son yirmi bir seneyi kapsayan onuncu bölümde hicri tarihler daha nadir olarak belirtilmiştir. Kitap kilise tarihine dair birçok bilgi içermekle beraber sadece bir kilise tarihi değildir. Hangi dönemde hangi devlet adamlarının görev yaptığı, dönemin siyasi tarihine ilişkin belli başlı olaylar, hicri takvimler de belirtilerek verilmiştir. Bu bölümler Osmanlı kronikleri ve diğer kaynaklarla karşılaştırılarak kullanıldığında oldukça yararlı olabilir. Fakat kitabı daha değerli kılan, Athanasios Komnenos Hypsilantis' in bulunduğu konum dolayısıyla kitabın içerdiği ayrıntılardır. Fenerli bir aileden gelmesi dolayısıyla Eflak ve Boğdan yönetimi ve bu bölgede görevli Fenerli aileler ve diğerleriyle ilgili içerdiği detaylı bilgiler kitabın içeriğini zenginleştirmektedir. Kitap, yazarının içinde bulunduğu sosyal çevre dolayısıyla İstanbul Patrikhanesine için de önemli bir kaynaktır. Özellikle sosyal ilişki ağları ve idarenin işleyiş mekanizmasıyla ilgili, çoğu zaman diğer kaynaklarda göremeyeceğimiz oldukça önemli ve ilginç ayrıntılar içermektedir. Athanasios Komnenos Hypsilantis, Ragıb Paşa'yla birlikte gittiği Urfa ve Halep'te bulunduğu dönemde Doğu Ortodoks kiliselerine yakın bulunmuş, bu kiliselerin sorunlariyla ilgilenmiş ve olaylara birebir tanıklık etmiştir. Athanasios, 1768-1774 Osmanlı Rus savaşı sırasında hizmet etmiştir, dolayısıyla kitabı bu konuda oldukça zengin malzeme sunmaktadır (Hypsilantis, 1972, s.421-539). 1778'de donanma tercümanı olarak Ruslarla görüşmek üzere görevlendirilmiş, Temmuz 1778' de Samsun'a ulaşmıştır (Hypsilantis, 1972, s.568-569). Veba salgınından çekindiği için gemiden ayrılmak istememiş, fakat karada hizmet etmek mecburiyetinde kalmış, Ruslarla görüştükten sonra nihayet İstanbul'a geri dönebilmiştir (Anastasios, 1981, s.128-129). Sonuçta 1768'den itibaren birebir tanığı olduğu Ruslarla ilgili olayları oldukça detaylı bir şekilde aktarma firsatı bulabilmiştir. Dolayısıyla Athanasios Komnenos Hypsilantis'in konumu gözönünde bulundurulduğunda çalışmasının sunduğu zenginlik açıkça görülmektedir.

\section{Hypsilantis ve Kilise Meselelerindeki Etkinliği}

Hypsilantis, hekimliği ve aldığı eğitim sayesinde önce Boğdan'da, daha sonra Ragıb Paşa'yla beraber gittiği yerlerde ve İstanbul'da önemli mevkilerde hizmet etmişti. İçinde bulunduğu ilişkiler ağ 1 ve çevresi, özellikle de Ragıb Paşa'yla olan bağlantısı sayesinde Ortodoks ve Müslüman aktörler arasında aracı pozisyona sahip olmuştu. Osmanlı Ortodoks kiliselerine dair meseleler, Hypsilantis'in çalışmasından yararlanılabilecek konulardan sadece biridir. Bu bölümde Hypsilantis'in çalışmasına, anlatısında durduğu yere ve üslubuna dair küçük çaplı bir örnek sunmak amacıyla kitapta bu konularla ilgili bulunan malzemeye bir göz atacağız.

Hypsilantis' in anlatısında kendi hayatına dair altını çizdiği bir şey, gerek Ragıb Paşa'nın yanında bulunduğu Urfa ve Halep'te gerekse İstanbul'a döndüğünde özellikle Ortodoks Patrikhanelerini ilgilendiren meselelerde ne kadar etkin bir rol oynadığıdır. On sekizinci yüzyıl ortasında Osmanlı Ortodoks 
Patrikhanelerinin tümünü ilgilendiren bir problem, Katolik misyonerlerin Ortodokslar üzerindeki etkisi ve özellikle Doğu Patrikhaneleri olarak adlandırılan Antakya, Kudüs ve İskenderiye kiliselerinin imtiyaz alanındaki yerlerde Katoliklerle ve Katolik taraftarı Ortodokslarla yaşadıkları iktidar mücadelesiydi (Çolak, 2015). Bu mücadelede Osmanlı idaresi, Ortodoks Osmanlı halkın Katoliklerin etkisi altında kalmasına karş1 çıkıyor, fakat aynı zamanda Katoliklerin hâmisi rolünde olan Fransızlarla arasındaki diplomatik ilişkileri dengede tutmaya çalıştığı için kimi zaman İstanbul'daki Katoliklerin temsilcileri iktidar mücadelesinde öne geçebiliyorlar, örneğin kendi tercih ettikleri ismi patrik olarak seçtirebiliyorlardı. Osmanlı Ortodoks toplumunun ileri gelenleri arasında da Katoliklere yakın olanlar ve karşı olanlar arasında bir çatışma yaşanıyordu. Bu kamplaşmada Hypsilantis şiddetli bir şekilde Ortodoksluğun tarafinda olmuş, Katolik taraftarlarına ve Batı kilisesinin Ortodokslar üzerindeki etkilerine ve kazanımlarına karşı çıkmıştır. Athanasios Hypsilantis bu konudaki çabalarında Ragıp Paşa ile olan bağlantısından faydalanmış, bu bağlantının farkında olan din adamları da -Athanasios'un aktardığına göre- problemlerinin çözümü için birçok defa kendisine başvurmuşlardır. Aynı şekilde Ragıp Paşa da kararlarını verirken Athanasios'un fikirlerinden yararlanmış görünmektedir.

Örneğin Athanasios 1744'te İskenderiye'deyken patrik Kosmas ile bir araya gelmiş, borç içindeki İskenderiye Kilisesi'nin kötü durumuna şahit olmuştu (Hypsilantis, 1972, s.352 ve Anastasios, 1981, s.126). 1751'den itibaren bulunduğu Urfa'dayken de o dönemde Ortodoks Patrikhaneleri için önemli bir sorun teşkil eden Katolik misyonerlerinin yarattığı problemlerle ilgilenmiş, Ragıb Paşa aracılığıyla zindana atılan metropolit Sofronios'u kurtarmaya çalışmıştır. Ragıp Paşa'nın kadıya (molla) yazdığı mektup üzerine Sofronios, Halep'teki Zekeriya Camii'ne 40 keselik bağış yapması şartıyla salıverilmiş, fakat bunu yerine getirmekte güçlük çekince önce Laodikeia (Denizli), daha sonra Patmos ve nihayet İstanbul'a kaçmıştır. Bu arada Katolikler 1751 'de Halep metropolitliğine Sofronios yerine Katolik taraftarı Maksimos'u yerleştirmeyi ve Ortodoksların ellerindeki kilise, kütüphane ve evleri almayı başarmışlardır (Hypsilantis, 1972, s.366 ve Anastasios, 1981, s.126). 1755'te Athanasios Ragıb Paşa'yla birlikte Halep'e gitmişti. Şam'da bulunan Antakya patriği Silvestros, Maksimos’tan (“Kako Maksimos”) kurtulmak için Athanasios’a mektup yazarak destek istemişti. Olayların karşı tarafındaki Maksimos'un erkek kardeşi hekim Mansuri Efendi de İstanbul'da sarayda görevliydi. Hypsilantis Maksimos’tan belge (hüccet) göstermesini istediğinde Maksimos, belgenin İstanbul'daki kardeşinde olduğu cevabını vermişti. Ragıp Paşa'nın yazışmaları ve arz sunması üzerine Maksimos Adana Kalesi'ne sürüldü ve yerine tekrar Sofronios atand. Fakat Sofronios Halep'e dönmeyi reddedince yerine başkasını bulamayan Antakya patriği, Hypsilantis ve İstanbul patriği Kyrillos'a mektup yazarak yeni birini bulmalarını istedi. Kyrillos'un bu durumla ilgilenmemesi üzerine metropolitlik makamı boş kaldı ve yeniden Katolik taraftarlarının eline geçti (Hypsilantis, 1972, s.372-373; Anastasios, 1981, s.127).

1757'de Ragıb Paşa'yla birlikte İstanbul'a dönen Hypsilantis, bu meseleyle ilgilenmeye devam etti. Yeni patrik Kallinikos'tan Halep'e yeni bir metropolit atamasını istedi. Patrik Kallinikos önce başka bir aday için mektup yazdı, fakat daha sonra kararından vazgeçerek Hypsilantis'i de geri adım atmaya zorladı. Halepli baştabip Mustafa Efendi, Mansuri Efendi ve kardeşi Maksimos iktidar mücadelesini kazanmıştı. Sonuçta Maksimos serbest bırakılarak metropolitlik makamına geri döndü. (Hypsilantis, 1972, s.374 ve Anastasios, 1981, s.128). Bu yıllarda Bilâd-1 Şâm'daki Ortodoks ve Katolikler arasındaki gerginliğin İstanbul'a da yansıdığını biliyoruz. Hypsilantis de bu rekabette Katolik karşıtı bir konum almış ve bunun için mücadele etmiştir. Muhtemelen bu çabalarının da etkisiyle Patrik Serafeim zamanında 1759 yılında onursal bir mevki olan skevofilaks unvanı ile payelendirilmiştir (Hypsilantis, 1972, s.383). Bir sonraki sene İstanbul' da patrik tarafından açılan ve önemli bir Ortodoks âlimi olan Evgenios'un ${ }^{25}$ da yer aldığı bir okulun komisyon üyesi olarak görev yapmıştır (Hypsilantis, 1972, s.385-386;Anastasios, 1981, s.127). Fakat okul

\footnotetext{
${ }^{25}$ Evgenios Boulgaris (1716-1806), 1742-1763 yılları arasında Yanya, Kozani, Aynoroz ve İstanbul'da öğretmenlik yapmış olan, Ortodoks eğitimi için çok önemli bir şahıstır. Batalden, S.K. (1982), Catherine II's Greek Prelate: Eugenios Voulgaris in Russia 1771-1806. New York: Boulder,

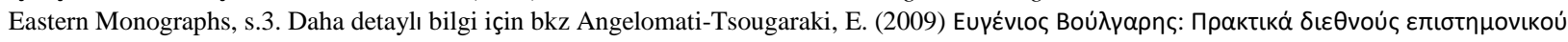

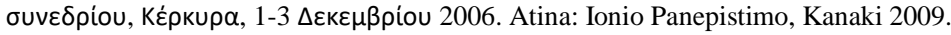


uzun ömürlü olmamış, bir süre sonra maddi zorluklar sebebiyle kapanmıştır (Hypsilantis, 1972, s.38; Athanasios, 1981, s.128).

Hypsilantis'in anlattığına göre Kudüs Patrikliğine yaptığı bir katkı da patrikliğe Parthenios’tan sonra seçilmek istenen Efraim'in tayini ile ilgili olmuştur. Parthenios, yerini Bethlehem metropoliti Efraim'e bırakmak istemiş, fakat İstanbul patriği Samuel buna önce itiraz etmiştir. Parthenios, bu şekilde Kudüs Patriklerinin Kaisaria metropolitleri arasından seçilmesi geleneğini bozan bir tercih yapmaktaydı (Çolak, 2015, s.150). Bunu başarmak için Parthenios, Athanasios'un Yeniköy'deki adresine bir mektup yazarak patrik Samuel ile görüşmesini istemiştir. Hypsilantis, patriğin kararını değiştirmeyi başardığını, ancak bunun için Patrikhane Hazinesi'ne 15 kese akçe verdiğini belirtir (Hypsilantis, 1972, s.409-410; Anastasios, 1981, s.128). Hypsilantis'in anlatısında genel olarak dikkat çeken bir şey de on sekizinci yüzyılda birçok problemin çözülmesi için belli bir miktar kese akçenin -devlet hazinesi veya Patrikhane hazinesine verilmek üzere- gözden çıkarılmak durumunda olmasıdır.

Athanasios Hypsilantis Doğu Kiliseleri meselelerinde kendisinin ima ettiği kadar etkili olmuş muydu? Hypsilantis' in kendisini önemli bir pozisyonda konumlandırdığ 1 meseleler ve Katolik etkisine karş1 Ortodoksluğu korumaya çalıştığı olaylar diğer kaynaklarda nasıl anlatılıyordu? Bu sorulara cevap aramak Hypsilantis'in çalışmasını değerlendirmek ve diğerleri arasında konumlandırmak açısından yararlı olabilir. Katolik Kilisesinin Ortodoks Hristiyanlar üzerindeki etkisinin bir problem olması on sekizinci yüzyıla özgü bir durum değildi. Fakat özellikle 1750'lerde İstanbul Ortodoks Patrikhanesinin iç ilişkilerini etkileyen bir faktör haline gelmişti. Bu konuda anti-Katolik tavrı en net olan ve popülist politikaları yüzünden İstanbul'da kendine karşı bir grubun oluşmasında etkili olan Kyrillos Karakallos'un Katoliklerin İstanbul'daki temsilcisi olan Fransızların etkisiyle 1757'de makamından nasıl uzaklaştırıldığını çağdaş kaynaklardan okumak mümkündür (Baron de Tott, 1785, s.108-112). Kyrillos’un yerine getirilen Kallinikos'un patriklik dönemi yalnızca altı ay sürecek, kısa bir süre sonra yerine Serafeim getirilecek ve Kallinikos Sina'ya sürülecektir (Hypsilantis, 1972, s.376). Serafeim'in Temmuz 1757'de patrik olduğu esnada sadrazam Koca Ragıp Mehmet Paşa'dır. Hypsilantis' in aktardığına göre, Patrik Kallinikos'tan zaman içinde rahatsız olmaya başlayan metropolitler (archiiereis), yerine başkasını seçmek için Sadrazam (epitropos) Ragıp Mehmet Paşa'dan izin isterler. Kallinikos bunu öğrenince sekiz gün boyunca saklanır. Aracılar, Sultan Osman'dan izin isteyerek Kallinikos'un ortaya çıkmasını sağlarlar. Ragıp Paşa, metropolitlere neye dayanarak patrik değiştirmeye izinleri olduğunu sorunca, onlar da önde gelen beş metropolitin patriği seçebilmelerini sağlayan eski tarihli bir ferman1, "Hayatizade olayı"nı hatırlatırlar. Buna göre 1741'de Kutsal Sinod'un en önemli metropolitleri olan beş metropolit (Ereğli, Kyzikos, İzmit, İznik ve Kadıköy metropolitleri) patriği seçebilecek, fakat aynı zamanda onun tüm davranışlarına da kefil olacaklardır. Bu durum Sinod metropolitlerinin zaman içinde patrikler karşısında güç kazanmalarına yol açacaktır. Ragıp Paşa'nın duruma hâkim olması sayesinde Sultan, Kallinikos'un uzaklaştırılmasına izin verir (Hypsilantis, 1972, s.375). Serafeim adet olduğu üzere Sadrazamı ziyaret ettiği sırada Ragıp Paşa, yeni patriğe "Ortodoksları gözetin!" buyurur (Orthodoksian giozetin) (Makraios, 1872, s.412). Makraios, Paşa'nın "bir doktora" ve özellikle divan baş tercümanı Gkikas'a güvenerek kilise işlerinde istedikleri gibi davranmalarına izin verdiğini kaydeder (Makraios, 1872, s.227). Makraios metnin son notlarında bu doktorun Athanasios Hypsilantis isimli dindar biri olduğunu, Patrikhanenin skevofilaksı ve daha sonra Rakovitza'nın protospatarios'u olduğunu bildirir (Makraios, 1872, s.412). Makraios'un anlatısında Athanasios'tan "bir doktor" olarak bahsediyor olmasına dayanarak, bu dönemde kendisinin en azından Hypsilantis ailesinin öne çıkan bireylerinden biri olmadığını söyleyebiliriz.

Bu örnekte gördüğümüz gibi Athanasios Hypsilantis'in çağdaşı olan kaynaklarda çok öne çıkan bir isim olmasa da Ragıp Paşa'nın kiliseye dair meselelerde verdiği kararlarda güvendiği bir isim olduğu açıtır. Ragıp Paşa, Urfa, Halep ve Mısır'da bulunduğu sırada yanında olan hekimi Athanasios'un da etkisiyle Katoliklerin Ortodoks Osmanlılar üzerindeki olumsuz etkilerine şahit olmuştu. Bu durumun hem bu bölgelerdeki görevleri sırasında hem de sonrasında Sadrazam olarak İstanbul'da bulunduğu dönemde Ortodokslarla ilgili verdiği kararları etkilemiş olduğunu söyleyebiliriz. Ayrıca belirtmek gerekir ki Ta meta tin Alosin Osmanlı din politikalarını belirleyen ve uygulayan aktörlerin kim olduğu meselesine katkıda bulunabilecek buna benzer birçok anekdot içermektedir. 


\section{Osmanlı Tarihyazımı Açısından Ta Meta tin Alosin}

Hypsilantis, Iulius Sezar döneminde başlayıp neredeyse on sekizinci yüzyılın sonuna kadar gelen bir çalışma kaleme almış, hekim olarak uzun süre bir Osmanlı devlet adamının yanında görevli bulunmuş olması sayesinde çalışmasının son bölümünü kendi tanıklıklarına dayanarak yazmıştır. Osmanlı tarih araştırmaları açısından taşıdığı öneme rağmen Hypsilantis'in çalışması fazla bilinmemekte, nadiren ve daha ziyade Kilise tarihi çalışmalarında kullanılmaktadır. Daha da önemlisi, Hypsilantis'in bugüne kadar Osmanlı tarihyazımına dair çalışmalarda bir Osmanlı müverrihi olarak değerlendirilmemiş olmasıdır.

Çalışmanın Osmanlı tarih araştırmalarında yaygın olarak kullanılmamış olmasının bir sebebi, eserin Rumca kaleme alınmış ve bugüne kadar başka bir dile tercüme edilmemiş olmasıdır. Rumca, Osmanlı toplumunda en çok konuşulan dillerden biri olmasına ve bu dilde yazılmış birincil kaynakların varlığına ve taşıdıkları öneme rağmen Osmanlı tarihi araştırmacılarının öncelikli olarak ilgi gösterdikleri bir kaynak dili değildir. Bununla birlikte, sadece Hypsilantis'in kitabının değil, Rumca diğer kaynakların da bugüne kadar Osmanlı tarihçilerinden uzak kalmış olması, dil probleminin yanısıra ana akım tarihyazımında Osmanlı gayrimüslimlerinin konumlandırılmasıyla da ilişkili olabilir. Birçok çalışmada on dokuzuncu yüzyılda bağımsız Yunan Devleti'nin kurulmasına yol açan isyan ve hareketlere dair bilgiler teleolojik olarak önceki yüzyıllar üzerine yansitılmış, Osmanlı döneminde Rum Ortodoksların tarihi ele alınırken isyan paradigmasından uzaklaşmak mümkün olmamıştır. Ancak isyan ve savaş döneminde Ortodoks toplumunun ve Fanariotların tamamının olaylar karşısında aynı tavrı takınmadıkları, Osmanlı yönetiminin dahi Rum Ortodokslara ve Fanariotlara yönelik tavrının homojen olmadığı ve gelişen olaylara bağlı olarak farklılık gösterdiği son zamanlarda yapılan çalışmalarda ortaya konmuştur (Ilıcak, 2011, s.168-202).

Tarihyazımında Hypsilantis ailesinin ismi, Yunanistan'ın bağımsız bir devlet olarak kurulmasıyla sonuçlanan "Yunan İsyanı"yla (veyahut "Yunanistan Bağımsızlık Savaşı"yla) yakından ilişkilendirilmektedir. İsyan döneminde Hypsilantis ailesinin bazı üyeleri çağdaş Osmanlı belgelerinde "firari" (Philliou, 2004, s.88), "hain" ve "baş sergerde" olarak nitelendirilmiştir. Dolayısıyla, Osmanlı perspektifinden bakıldığında devlete "ihanet" ettiği düşünülen, Yunanistan bağımsızlığı perspektifinden ise "kahraman" sayılan Aleksandros ve Dimitrios Hypsilantis kardeşlerin büyük dedeleri olan Osmanlı Ortodoks toplumunun üyelerinin de benzer bakış açısıyla algılanarak gözardı edilmesi, bu bireylerin on sekizinci yüzyıldaki pozisyonlarına yönelik bakıșı olumsuz bir şekilde etkileyebilir. Bu durum sadece Hypsilantis ailesi için değil, tarihyazımında Osmanlı Rum Ortodoks toplumunun diğer önde gelen ailelerini ele alan çalışmalar için de geçerlidir.

Osmanlı dönemindeki gayrimüslimlere, Fener ailelerine ve ürettikleri çalışmalara yönelik yaklaşım, yalnızca Osmanlı tarihi açısından değil Yunanistan ve Bizans tarihi perspektifinden yaklaşanlar tarafından da olumsuz bir açıdan değerlendirilegelmiştir. Örneğin Hypsilantis'in kullandığı dil Osmanlıca terimlerle dolu olduğu için eleştirilmiş, "dönemin miksovarvaros olarak bilinen, eski kilise dilinin Türkçe terimlerle karıştığı korkunç bir jargonla" yazıldığı belirtilmiştir (Pallis, 1951, s.3) ${ }^{26}$ Fener ailelerinin ne derece "Bizanslı" olduklarını kanıtlama çabası on sekizinci yüzyılda voyvodalıklarda görevlendirilen seçkin Ortodoks aileler arasında bir asalet ve güç konsolidasyonu çabası olarak değerlendirilebilir. Yirminci yüzyılda bu iddiaların Bizans tarihçileri tarafından sorgulanıp çürütülmesi ise Osmanlı döneminde bu ailelerin devletle uyumlu ilişkilerine ve sistem içindeki işleyiş̧lerine yönelik bir eleştiri ve aslında "milli" olmadıklarını [anti-national] ve ana eksenlerinin Kilise olduğunu kanıtlama çabasıyla ilişkilidir (Mango, 1973, s.59, 66). Fener ailelerini Yunan milliyetçiliğinin karşısına yerleştiren bakış açısı, Filiki Etaireia içinde yalnızca birkaç Fanariot olduğunu, hatta Aleksandros Hypsilantis'in Rusya'da yetiştiği için aslında Fenerli bile sayılamayacağını not eder (Patrinelis, 2001, 197). Tüm bunlara rağmen artık son dönemde keskin dikotomilerden kaçınmayı başaran çalışmalar da ortaya çıkmaya başlamıştır (Philliou 2004, Philliou 2009).

\footnotetext{
${ }^{26}$ Metne daha olumlu yaklaşanlar ise Hypsilantis'in güzel bir Yunanca kullanıldığını fakat 'yabancı' terimleri anlamak için sözlük gerektiğini belirtmiştir (Anastasios, 1981, 130).
} 
Gayrimüslim Osmanlıların ürettiği çalışmaların Osmanlı araştırmalarında bugüne kadar yaygın olarak bilinmemesi Hypsilantis'in çalışmasına özgü bir durum değildir. Osmanlı idaresi altında yaşayan gayrimüslimler on yedinci yüzyıl sonundan önce kayda değer ve kapsamlı tarih çalışmaları kaleme almak yerine yerel ve sadece kiliseye dair metinler üretmişlerdir. Johann Strauss, bunu öncelikle eğitim olanaklarının yetersizliğiyle fakat daha da önemlisi bir tarihçi için en gerekli unsurlardan biri olan patronaj yokluğuyla açıklar. Bu durum on yedinci yüzyıl sonu ve on sekizinci yüzyıl başında imparatorluğun çevresinde yeşeren kültürel merkezler sayesinde değişmeye başlar. Eflak ve Boğdan voyvodalıklarının 1711'den itibaren Fanariot olarak bilinen İstanbullu Ortodokslar tarafindan idare edilmesiyle başlayan dönemde voyvodaların desteklediği kültürel ve politik ortam ilk ürünlerini vermeye başlar (Strauss, 1999, s.217). Voyvodalıklarda on sekizinci yüzyıl başından itibaren Rumca veya Romence yazılan ve tercüme edilen çalışmalar artmaya başlar, fakat önemli içeriklerine rağmen yazma olarak kaldıkları için geniş bir okuyucu topluluğuna hitab etmezler ve etkileri sinırlı kalır. Fakat on sekizinci yüzyıldan itibaren Dimitri Kantemir, Ienachita Vacarescu, Athanasios Komnenos Hypsilantis, Kaisarios Dapontes gibi gayrimüslim yazarlar tarafından üretilen tarih çalışmaları ortaya çıkmaya başlar (Strauss, 1999, s.219-232).

Hypsilantis'in ve diğer gayrimüslim Osmanlı tarihçilerinin çalışmalarının bilinmemesi ve kullanılmaması dışında bir diğer durum da bu çalışmaları üreten yazarların çağdaş Osmanlı tarihçileri arasında sayılmamasıdır. Osmanlı tarih yazıcılığı bugüne kadar Ortadoğu tarihyazımı geleneğinin bir parçası olarak değerlendirilmiş, Osmanlı tarih yazarları Arap veyahut Fars kültürel geleneği içerisinde konumlandırılmıştır (Karateke, 2013 ve Hagen, Menchinger, 2014). Gayrimüslim yazarların çalışmaları ise ayrı bir kategori olarak ele alınmış ya da tamamen göz ardı edilmiştir. Örneğin Ta meta tin Alosin’i Osmanlı tarihyazımı açısından inceleyen nadir çalışmalardan biri olan Johann Strauss, bu çalışmanın Fanariot tarihçiliğinin zirvesi olduğu görüşündedir (Strauss, 1999, s.226). Osmanlı toplumunun bir parçası olan Fener ailelerinden birine mensup bir İstanbullu olan, çeşitli devlet hizmetlerinde görev almış ve toplumda yaygın bir dil olan Rumca bir çalışması bulunan Hypsilantis de Osmanlı tarihyazımı geleneğinin bir parçası olarak değerlendirilmelidir.

Hypsilantis'in Osmanlı Ortodoks kimliği, kitabının dönemlendirme ve tarihlendirme gibi yapısal özelliklerine yansımıştır. Hizmet ettiği pozisyonlar ve konumunun getirdiği avantajlar bilhassa tanıklık ettiği dönemlere dair içeriği belirlemiş ve zenginleştirmiştir. Çalışmanın ilk göze çarpan özelliklerinden biri olan Osmanlıca terimlerin fazlalığı, Osmanlı idaresinin öğelerine ve işleyişine dair zengin bilgi potansiyeli, Osmanlı idaresince de desteklenen "Ortodoksluğu Katolikler gibi 'yabanc1' etkenlerden koruma” güdüsü gibi diğer unsurlar da göz önüne alınırsa, Athanasios'un kimliğinin, Osmanlı dünyasının doğal bir yansıması olarak oldukça zengin ve karmaşık olduğunu görürüz. Devlet/toplum, idareci/idare edilen gibi karşıtlıklar yerine bunların iç içe geçtiği kimliklerin farkına varmak ve aslında Osmanlı toplumunun sosyal, ekonomik ve politik atmosferinden eşit derecede etkilenen Müslüman ve gayrimüslim unsurların çoğu zaman birbirinin nüfuzlarından faydalanan karşılıklı bir etkileşim içinde işlediklerini kabul etmek, Osmanlı gayrimüslimlerinin tecrübelerini doğruya daha yakın bir şekilde kavrayabilmek için gerekli olan bir yaklaşımdır. Athanasios Komnenos Hypsilantis gibi çok yönlü bir kimliğin ortaya koyduğu bir çalışma olan Ta Meta tin Alosin tarihyazımının etkilerinden masun bir gözle değerlendirildiğinde Osmanlı araştırmaları için oldukça zengin bir malzeme sağlayacaktır. Hypsilantis gibi Osmanlı Ortodoks yazarların ortaya koyduğu ürünlerin dil, dönemlendirme, içerik açısından incelenmesi ve bu doğrultuda Osmanlı tarihyazımı üzerine yeniden düşünülmesi gerekir. 


\section{Kaynakça}

Aktepe, M. (1958). Patrona isyanı (1730). İstanbul: İstanbul Üniversitesi Edebiyat Fakültesi.

Anastasios, I. E. (1981). Athanasios Komnenos Hypselantes: A biographical sketch. Greek Orthodox Theological Review, 26, 125133.

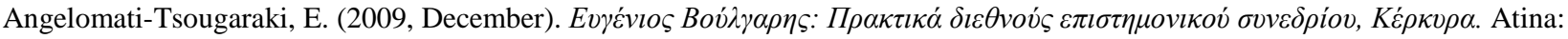
Ionio Panepistimo, Kanaki.

Arš, G. L. (1985). On the life in Russia of the Greek patriotic family of Ypsilanti. Balkan Studies, 26, 73-90.

Aydıner, M. (2007). Râgıb Paşa. Türkiye Diyanet Vakfi İslam Ansiklopedisi (c. 34, s. 403-406). Ankara: Türkiye Diyanet Vakfi.

Balcı, S. (2004). Osmanlı Devleti'nde tercümanlık ve Bab-ı Ali tercüme odası. (Doktora tezi). Ankara Üniversitesi, Ankara.

Baron De Tott F. (1785). Memoirs of the baron de tott on the Turks and the Tartars. Dublin.

Batalden, S. K. (1982). Catherine II’s Greek Prelate: Eugenios Voulgaris in Russia 1771-1806. New York: Boulder, Eastern Monographs.

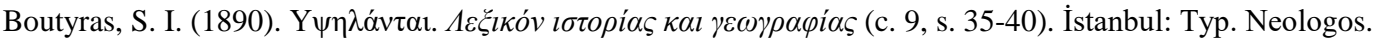

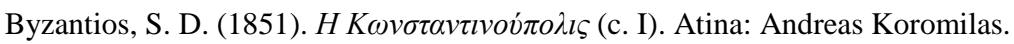

Çolak, H. (2015). The Orthodox church in the early modern Middle East: Relations between the Ottoman Central administration and the patriarchates of Antioch, Jerusalem and Alexandria. Ankara: TTK.

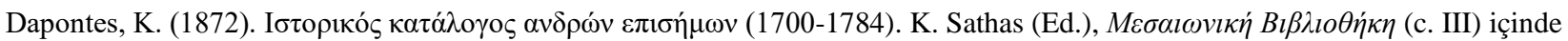
(ss. 72-200). Venedik: Typois tou Chronou.

Dapontes, C. (1881). Ephemerides Daces ou chronique de la guerre de quatre ans (1736-1739). Paris: Leroux.

Davidova, E. (2013). Balkan Transitions to Modernity and Nation-States Through the Eyes of Three Generations of Merchants (1780s-1890s). Leiden: Brill.

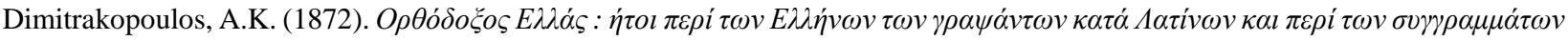
$\alpha v \tau \omega ́ v$. Leipzig: Metzger\&Wittig.

Foster, G. L. (1857). The past of Ypsilanti: A discourse. Detroit: Fleming \& Davis.

Frangos, G. D. (1971) The Philiki Etaireia, 1814-1821: A social and historical analysis. (Doktora Tezi). Columbia Üniversitesi, New York.

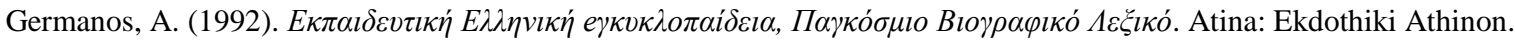

Hagen, G. ve Menchinger, E. (2014). Ottoman historical thought. P. Duara, V. Murthy, A. Sartori (Eds.), A Companion to Global Historical Thought içinde (ss. 92-106). Chichester: Wiley-Blackwell.

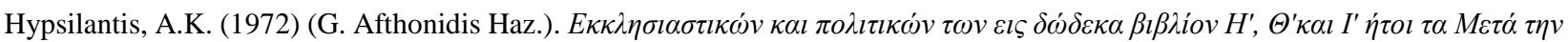
$A \lambda \omega \sigma l v$ (1453-1789). Atina: Noti Karavia (1870 baskisının yeniden basimı).

Ilıcak, H. Ş. (2011). A radical rethinking of the Empire: Ottoman State and Society during the Greek War of Independence (18211826). (Doktora Tezi). Harvard Üniversitesi, Cambridge, Massachusetts.

Iorga, N. (2000). Byzantium After Byzantium. Iaşi, Oxford, Portland: The Center for Romanian Studies.

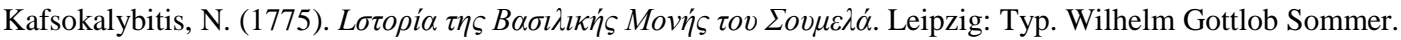

Karateke, H. (2013). The challenge of periodization: New patterns in nineteenth century Ottoman historiography. E. Fetvac1, H.E. Çıр (Eds.), Writing History at the Ottoman Court: Editing the Past, Fashioning the Future içinde (ss.129-154). Bloomington: Indiana University Press.

Kazhdan, A. (1991). Xiphilinos. The Oxford Dictionary of Byzantium. Oxford University Press.

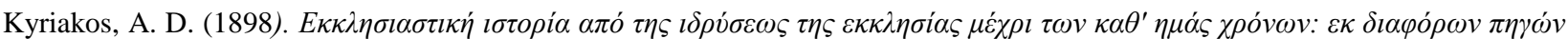
$\varepsilon \rho \alpha v \imath \sigma \theta \varepsilon i \sigma \sigma$ (c. 3). Atina: Typ. Anesti Konstantinidou.

Magdalino, P. ve Talbot, A.M. (1991). Skeuophylax. The Oxford Dictionary of Byzantium. Oxford University Press.

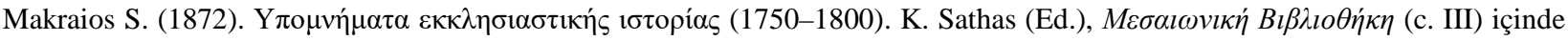
(ss. 203-419). Venedik: Typois tou Chronou.

Mango C. (1973). The Phanariots and the Byzantine tradition. R. Clogg (Ed.), The Struggle for Greek Independence içinde (ss. 4166). London: Macmillan.

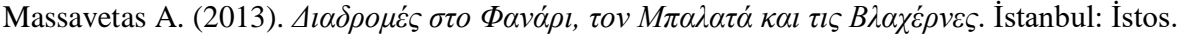

Pallis, A. A. (1951). The Phanariots. A Greek aristocracy under Turkish rule. King’s College, Londra 
Papadopoullos, T. H. (1990). Studies and documents relating to the history of the Greek Church and people under Turkish Domination. Aldershot: Variorum.

Patrinelis, C. G. (2001) The phanariots before 1821. Balkan Studies, 42 (2), 177-198.

Philliou, C. M. (2004). Worlds, old and new: Phanariot networks and the remaking of Ottoman governance in the first half of the nineteenth century. (Doktora tezi). Princeton Üniversitesi, New Jersey.

Philliou, C. M. (2009). Communities on the verge: Unraveling the phanariot ascendancy in Ottoman governance. Comparative Studies in Society and History, 51 (1), 151-181.

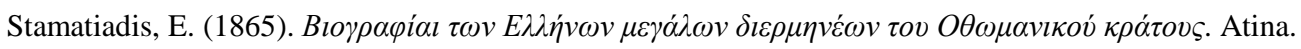

Strauss, J. (1999). The rise of Non-Muslim historiography in the eighteenth century. K. Fleet (Ed.), Oriente Moderno, 18 (79), $217-$ 232. urdza, M. D. (1983). Dictionnaire historique et généalogique des grandes familles de Grèce, d'Albanie et de Constantinople. Paris.

Tibet, A. (1994). İpsilanti Yalısı. Dünden bugüne İstanbul ansiklopedisi, (c.4, ss.185-186). İstanbul: Kültür Bakanlığ1 ve Tarih Vakfi.

Uzunçarşılı, İ. H. (2007). Osmanlı tarihi, (c. 4). Ankara: TTK.

Yılmaz, H. (2016). İsyânın gölgesindeki İstanbul: Yeni arşiv belgeleri 1şı̆̆ında 1730 Patrona İsyânı. (F.M. Emecen, A. Akyıldız, E.S. Gürkan, Ed.), Osmanlı İstanbulu IV içinde (ss. 411-452). İstanbul: İstanbul 29 Mayıs Üniversitesi Yayınları. 